\title{
Leadership Styles of Secondary School Principals and Teachers' Job Satisfaction in Yenagoa Local Government Area of Bayelsa State, Nigeria.
}

\author{
*Meindinyo, R.O.K., \#Ibara, E.C, and Tuatongha, C*. \\ *Isaac Jasper Boro College of Education, Sagbama, Bayelsa State, Nigeria* \\ \#Department of Educational Management, Rivers State University of \\ Education, Rumuolumieni Port Harcourt, Nigeria\#.
}

\begin{abstract}
This study examined the leadership styles of Secondary School Principals and Teachers' Job satisfaction in Yenagoa Local Government Area of Bayelsa State. The study adopted the descriptive research design. The population of the study comprises three hundred and ninety-nine (399) teachers and the sample for the study consisted of One hundred and Seventy-five (175) teachers. Two research questions were raised to guide the study. The chi-square $\left(x^{2}\right)$ statistical analysis was utilized to test the hypothesis at 0.5 level of significance.The findings of the study include; that the teachers were satisfied with only three (3) out of the fifteen (15) leadership styles examined in the study. These are group consultative decision making participant/supportive and supportive consultative styles of leadership. These represent just about twenty percent (20\%) of the leadership styles listed in the questionnaire. This implies that the teachers were dissatisfied with eight percent (8\%) of the leadership styles adopted by most heads of organizations. Based on the findings some recommendations were made to enhance teachers job satisfaction in Yenagoa Local Government Area of Bayelsa State.
\end{abstract}

Keywords: Leadership styles, Job satisfaction, principals, Teachers, Autocratic.

\section{Introduction}

One of the major challenges confronting many organizations including the educational system is the presence of effective leadership at the helm of affairs. According to stoner (1982) and Bernard (2006), the difference between a successful organization and an unsuccessful one is the presence of an effective and dynamic leader. In his view, leadership is concerned with the directing function on the staff personnel and that in administration what one need is to understand more than the enforcement of obedience, thus when we lead we motivate, influence, guide or stimulate the action of people towards the achievement of the stated organization goals. To achieve these, the chief executive must apply the correct style of leadership, making sure discipline is maintained as well as the ability to give the right instructions. Darling-Hammond et al (2007), Zakaria (2012) and Ajanaku,(2012) The problem of school today is not the lack of people to fill administrative posts, but scarcity of people who are willing to assume significant leadership roles.

One of the major challenges faced by secondary schools (principals) is poor attitude to work by the teachers. This usually manifest in various forms like massive desertion, redundancy, frustration, discouragement and absenteeism, unmotivated demoralized teachers. This has contributed to poor academic performance of students in our secondary schools, and also in the senior school certificate examinations in recent times. Infact Bayelsa State has been acclaimed to come last in terms of performance in most public examination like West Africa School Certificate (WASC) and National Examination Council (NECO). Poor attitude to work by teachers which may be contributing to the abysmal performance of students in examinations attributable to inappropriate leadership styles adopted by some school principals (Ogbowei, 2008).

In tandem with the foregoing, the leadership style is conceptualized as the behavior of officiallydesignated heads of schools in Yenagoa Local community organizations are becoming increasingly interested or invested in the quality our public schools. Training programs for school leaders have been in existence at many levels, but new and innovative programs are being established. In the United States some states have incorporated standards-based assessments into the licensure process for principals as reported by Gates et al(2007). The issue has also capture the attention of the Federal Government, and Congress in the United States is considering support for several leadership programs such as:

- The School Leadership Initiative, which would allocate $\$ 40$ million to establish regional centers to deliver professional development training for principals, particularly those working in high-poverty, lowperforming schools. The program could eventually provide much-needed training for 10,000 school leaders.

- The LEAD (Leadership Education and Development) Program, which would authorize $\$ 100$ million in grants to help states and agencies provided leadership education, recruitment, and mentoring programs for 
principals and other school leaders (National Association of Elementary School Principals and National Association of Secondary School Principals, 1998).

It is known that Schools Leaders (that is principals, assistant principals, lead the teacher. According to Adesina (1989)the principal is the person with the sole responsibility of running a school. The principal is described thus because he is responsible for policy decisions, he determines the direction and objective of the school.

The leader, in effect, must have the vision; he articulate, sets the styles and tone for the operations. He must provide the optimism and determination in times of difficulties. The leader is supposed to source of inspiration, wise counsel, energy and meaning, since leadership implies the conscious direction force, making for a change in organization.

The principal as a leader should be more interest not only in making his teachers perform their duties effective but also more importantly, in helping them to achieve, as well as satisfactorily carry out their duties and aspiration while meeting the corporate goals and objectives of the schools.

In fact school leadership has become a much-talked-about topic recently, fueled by a long-standing concernover the quality of primary and secondary education in Nigeria and other parts of the world in general. Multiple stakeholders (that is educators, parent, student, policymakers, social service agencies, and teachers) are those charged to make decisions about how a school operates and meets expectations. These decisions range from administering high-level and strategic programmatic plans-such as choosing a curriculum framework and delineating a primary pedagogical approach to be used through the school-to handling more administrative and operational issues such as determining the school bus schedule. Leaders are also held accountable for performance on multiple dimensions including student performance on multiple dimensions including student performance on standardized tests, attendance, school safety, and graduation rates. School leaders are responsible to many stakeholders (parents, the school board, students, and the district, state, and federal government) and are expected to balance their many, often-conflicting demands, while always maintaining student learning as the central focus (Gates et al 2007).

One reason school leadership is a particularly important issue is that many of the current school reform initiatives, in order to be successful, require active leadership support and participation. Some reform effortssuch as voucher programs, charter schools, and site-based management are predicted on a view that strong and appropriate school leadership matters. The challenge is that often, good leaders are inhibited by the many rules, regulations and restrictions imposed at the district, state, and federal level. Designers of some reform Government Area, Bayelsa State, when they are directing the activities of their teachers towards achieving the goals of the schools. The study of leadership behaviour in work situation has long been an area of interest to researchers especially in the field of industrial psychology and educational administration. Since satisfaction with the leadership styles of the chief executive is one motivation for performance, the researcher therefore attempts to examine teachers' satisfaction with the leadership styles of the secondary school principals in Yenagoa Local Government Area of Bayelsa State with a view to recommending ways of improving their leadership styles, where necessary. Some researchers have been carried out in the area of leadership styles as this may influence teachers satisfaction Gates (2002), but non has so far been carried out in Bayelsa State to examine and address this ugly case. The ugly situation highlighted above and trend which has attracted the attention of the public, all stakeholders alike would want to know if this is actually responsible. It is against this background, that this study was therefore designed to fill that gap to determine the extent to which teachers satisfaction may be related to the leadership styles of secondary school principals using schools in Yenagoa Local Government Area as case study.

The following research questions were examined in the study.

1. What leadership styles of the secondary school principle areteachers satisfied with?

2. To what extent does teachers' job satisfaction depend on the leadership styles of the secondary school principals?

The following null hypothesis are formulated from the research questions and tested at the 0.05 confidence level.

1. Teachers will not differ in their level of satisfaction and the leadership styles of school principals.

\section{Methodology}

The study adopted an opinion survey design which sought to determine teacher's satisfaction with the leadership styles of principals.

\section{Population And Sample}

The population for the study comprised 399 secondary teachers in Yenagoa Local Government Area of Bayelsa State. A sample size of 175 subjects was selected using probability sampling technique. 


\section{Instruments}

For the purpose of data collection, the teachers' assessment of principals' leadership styles questionnaire was used for this study. It was structured in very simple form for easy understanding of the teachers to respond accurately. 170 questionnaires were returned out of the 175 copies distributed and ten were unusable.

\section{Results}

Data were analyzed according to the research questions and hypothesis in the study. Items in the questionnaire were subjected to a decision rule of 2.50 as mean and items with mean value of below 2.50 were classified as dissatisfying style while those above 2.50 were accepted as satisfied leadership style as shown below in table 1 and figure 1.

Table 1: Relationship between teachers' job satisfaction and leadership styles of college principals.

\begin{tabular}{|c|c|c|c|c|c|c|c|}
\hline \multirow[t]{2}{*}{ S/NO } & \multirow[t]{2}{*}{ Leadership Styles } & \multicolumn{5}{|c|}{ Levels of Satisfaction } & \multirow[t]{2}{*}{ Remarks } \\
\hline & & SS & $\mathrm{S}$ & $\mathrm{D}$ & SD & $\overline{\mathrm{X}}$ & \\
\hline 1 & Consultative/Participative Decision & 45 & 31 & 31 & 47 & 2.39 & Dissatisfied \\
\hline 2 & Directive (Autocratic) & 34 & 38 & 31 & 38 & 2.19 & Dissatisfied \\
\hline 3 & Coercive (Autocratic) & 25 & 34 & 36 & 55 & 2.06 & Dissatisfied \\
\hline 4 & Laissez-faire (“Hand-of”) & 16 & 20 & 34 & 80 & 1.7 & Dissatisfied \\
\hline 5 & Employee-Centered (Laissez-faire) & 19 & 28 & 40 & 63 & 1.89 & Dissatisfied \\
\hline 6 & Majority Consensus (Democratic) & 43 & 41 & 31 & 22 & 2.31 & Dissatisfied \\
\hline 7 & Group Consensus Decision-making (Democratic) & 57 & 43 & 22 & 38 & 2.67 & Satisfied \\
\hline 8 & $\begin{array}{l}\text { Laissez-faire (Freedom to criticize and make work } \\
\text { related decisions) }\end{array}$ & 24 & 45 & 32 & 49 & 2.09 & Dissatisfied \\
\hline 9 & Democratic (Participative/Supportive) & 55 & 60 & 20 & 15 & 2.5 & Satisfied \\
\hline 10 & Autocratic (Task-oriented/Supportive) & 27 & 42 & 40 & 41 & 2.22 & Dissatisfied \\
\hline 11 & Democratic (Task-oriented/Supportive) & 27 & 49 & 41 & 33 & 2.31 & Dissatisfied \\
\hline 12 & Autocratic (Directive/Achievement-oriented) & 29 & 50 & 34 & 37 & 2.32 & Dissatisfied \\
\hline 13 & Autocratic (Directive/Task-oriented) & 41 & 41 & 30 & 38 & 2.41 & Dissatisfied \\
\hline 14 & Democratic (Supportive/Consultative) & 41 & 52 & 32 & 25 & 2.60 & Satisfied \\
\hline 15 & Autocratic (Achievement-oriented) & 38 & 47 & 30 & 35 & 2.43 & Dissatisfied \\
\hline
\end{tabular}

Teachers were satisfied with only 3 out of the fifteen leadership styles.

\begin{tabular}{|l|l|l|l|l|l|}
\hline S/N & LEADERSHIP STYLES & \multicolumn{4}{|l|}{ LEVEL OF SATISFACTION } \\
\hline & & SS & S & D & SD \\
\hline 1 & Group Consensus Decision Making & 57 & 43 & 22 & 28 \\
\hline 2 & Participative/Supportive & 55 & 60 & 20 & 15 \\
\hline 3 & Supportive/Consultative & 41 & 52 & 32 & 25 \\
\hline
\end{tabular}

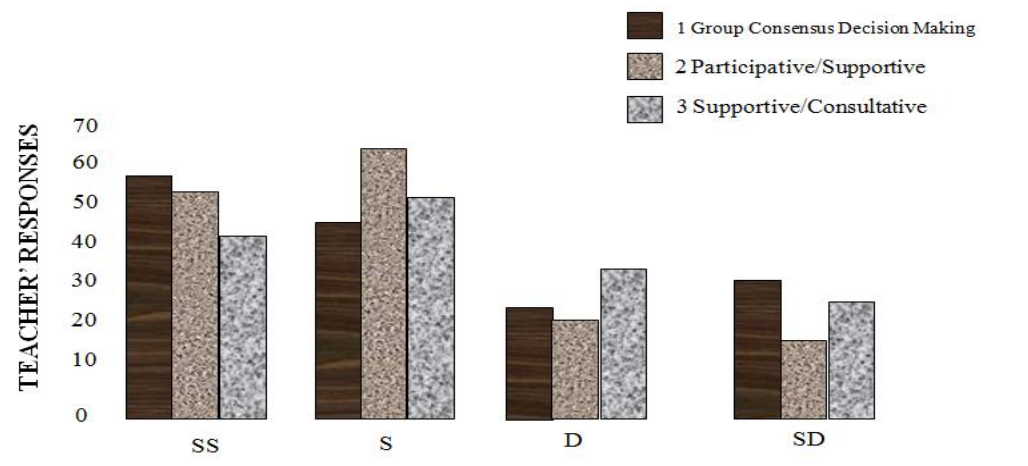

LEVELS OF SATISFACTION

Figure 1: Graphical Representation of Teachers' Responses Against Levels of Satisfaction 
Further, table $2 \mathrm{a}$ and $2 \mathrm{~b}$ show the summarized data of hypothesis $1\left(\mathrm{Ho}_{1}\right)$ subjected to statistical analysis using contingency chi-square analytical procedures below:

Table 2 (a): Observed frequencies (of) and expected frequencies (ef) of assessment of Principals' leadership styles and teachers job satisfaction

\begin{tabular}{|l|l|l|l|l|l|l|}
\hline S/NO & Leadership Styles & \multicolumn{2}{l|}{$\begin{array}{l}\text { Teachers' } \\
\text { Responses }\end{array}$} & $\begin{array}{l}\text { Teachers' } \\
\text { Responses }\end{array}$ & $\begin{array}{l}\text { Observed } \\
\text { Mean }\end{array}$ \\
\cline { 3 - 7 } & & Satisfied (S) & \multicolumn{2}{l|}{ Dissatisfied (S) } & Total \\
\hline 1. & Group Consensus Decision-making & 100 & 102.7 & 50 & 47.3 & 150 \\
\hline 2. & Participative/Supportive & 115 & 102.7 & 35 & 47.3 & 150 \\
\hline 3. & Supportive/Consultative & 93 & 102.7 & 57 & 47.3 & 150 \\
\hline & TOTAL & $\mathbf{3 0 8}$ & & $\mathbf{1 4 2}$ & & $\mathbf{4 5 0}$ \\
\hline
\end{tabular}

S-Satisfied, D-Dissatisfied

Table 2 (b): Chi-suqare on the relationship between Principals effective leadership styles and teachers' job satisfaction.

\begin{tabular}{|c|c|c|c|c|c|c|}
\hline \multirow{2}{*}{ S/NO } & \multirow{2}{*}{ Leadership Styles } & \multicolumn{4}{|c|}{$\mathrm{C}_{1}$} & \multirow[b]{2}{*}{$\frac{\backslash \mathrm{of}-\mathrm{ef} /^{2}}{\text { ef }}$} \\
\hline & & of & ef & lof - ef/ & lof $-\mathrm{ef} / /^{2}$ & \\
\hline 1. & Group Consensus Decision-making & $\begin{array}{l}\text { S } 100 \\
\text { D } 50\end{array}$ & 102.7 & $\begin{array}{l}2.7 \\
2.7\end{array}$ & $\begin{array}{l}7.29 \\
7.29\end{array}$ & $\begin{array}{l}0.0710 \\
0.1541\end{array}$ \\
\hline 2. & Participative/Supportive & $\begin{array}{l}\text { S } 115 \\
\text { D } 35\end{array}$ & 102.7 & $\begin{array}{l}12.3 \\
12.3\end{array}$ & $\begin{array}{l}151.29 \\
151.29\end{array}$ & $\begin{array}{l}1.4731 \\
3.1985\end{array}$ \\
\hline 3. & Supportive/Consultative & $\begin{array}{l}\text { S } 93 \\
\text { D } 57\end{array}$ & 102.7 & $\begin{array}{l}9.7 \\
9.7\end{array}$ & $\begin{array}{l}94.09 \\
94.09\end{array}$ & $\begin{array}{l}0.9162 \\
1.9892\end{array}$ \\
\hline & & & & & & 7.8021 \\
\hline
\end{tabular}

Source: fieldwork, 2012

S-Satisfied, D-Dissatisfied

Significant at $\mathrm{p}<0.05, \mathrm{df}=2$, critical $\mathrm{X}^{2}=5.99$

Tables $2 \mathrm{a}$ and $2 \mathrm{~b}$ indicate that the calculated chi-square value of 7.8021 is greater than the critical $\mathrm{X}^{2}$ value of 5.99 at 0.05 alpha levels of significance with 2 degree of freedom. We therefore reject the null hypothesis and accept the alternative hypothesis which states that teachers' will differ in their level of job satisfaction and the leadership style of the school principal.

\section{Discussion}

Our findings as indicated in tables $2 \mathrm{a}$ and $2 \mathrm{~b}$ which revealed that there is relationship between teachers' level of job satisfaction and the leadership style by a school principal is consistent with the work of Darling -Hammond (2007) whose research suggested that definite personnel policies and professional practices such as making regular classroom visits, communicating instructional goals and promoting discussions on instructional issues based on feedback must be employed by a school head if he is to succeed. Also, job satisfaction revealed that lack of effective leadership skills negatively affected teachers' job satisfaction. Some secondary school teachers had expressed dissatisfaction with their work due to unconducive environment created by administrative flaws. It also has been revealed that teachers feel dissatisfaction in school environment that do not provide opportunities for teacher's development. For several decades, secondary schools in Bayelsa State were plague with a series of strike actions carried out by teachers. When compared with their colleagues in other professions, teachers were not getting the kind of satisfaction they ought from teaching. It was evident that some teachers abandoned classrooms for other jobs because of lack of interest and satisfaction.

Also consistent with the result of our findings is the work of Musaazi (1982) which revealed that good leaders should promote the involvement of teachers and parents in the decision-making process. This researcher further concluded that excellent principals are not threatened by this empowerment.

\section{Conclusion}

From the study the following findings had been observed.

i. Teachers' level of job satisfaction is high, when teachers are

Satisfied with their principal's leadership style.

ii. Implicitly teachers' attitude to work is also affected characterized byVarious deviant behaviors. 


\section{Reference}

[1]. Abu-Hussain, J.(1998).Value systems and leadership styles of school principals in Israel's Arab sector. In: Studies in educational Administration and Organisation, 22, 87-100 (Hebrew).

[2]. Abu-Hussain, J.\& Essawi, M. (2014) Value Orientation and Leadership Style among School Principals in Israel's Arab Education System, International Journal of Business Administration, Sciedu Press, Vol.5, N3,49-58.

[3]. Adams, J., Khan, H. T. A., Raeside, R. \& White, D.S.(2007). Research method for graduate business and social science students USA:Sage Publications Inc.

[4]. Adeyemi, T.O. (2004).Educational Administration, an Introduction, Ado-Ekiti Green line Publishers.

[5]. Adeyemi,T.O.(2006).Fundamentals of Educational Management. Lagos: Atlantic Associated Publishers. pp. 21-60.

[6]. Adepoju, T.L.(1996).The factors militating against effective planning and implementation of Educational policies in Nigeria. A paper presented at the WAEC monthly seminar, WAEC National SecretariatYaba, Lagos, Feb. 28.

[7]. Ajayi I.A, Ayodele, J.B.(2001).Introduction to educational planning, Administration and supervision"Yemi Publishing Services, Ado-Ekiti.pp. $\quad 56-78$.

[8]. Ajai, S .G. (2009).Statistical method for practice and research :(2nded.).New Delhi:SAGE.

[9]. Akinyemi.A(1993). Job satisfaction among teachers in Ondo State secondary school". J. Educ. Leadership, 29: 10-22.

[10]. Alagheband. (1997). The study of relationship between supervisor educational philosophy and their practice. Tehran University, Iran.

[11]. ArmStrong, M., H. \& Trueblood, C. (1985). The Importance of Principals' Values and their Relationship to the Promotion of Professional teachers Growth, Eric Document Reproduction Service (ED263668).

[12]. Bar-El, Z.; Nomeir, M. (1993). Meetings with psychology, Pub; Reches, (Hebrew).

[13]. Bennett, N. \& Anderson, L. (2003). Rethinking educational leadership. Sage publications Ltd, London.

[14]. Bolden, R., Gosling, J., Marturano, A. \& Dennison, P. (2003). A review of LeadershipTheory and Competency Frameworks, Centre for Leadership Studies, University of Exeter, Cross mead Barley Lane Dunsford Hill Exeter EX4 !TF United Kingdom.

[15]. Brech, E. F. L. (1969). Management: its nature and significance. London:Pitman.

[16]. Bredeson,P. V. (2003). Designs for learning. Thousand Oaks: Corwin Press.

[17]. Brownwell, J. (1985). A model for listening instruction: management applications. Bulletin of the Association for Business Communications, $48: 39-44$

[18]. CfBT. (2008). Study into teacher utilization in the Regions of Ethiopia. Addis Ababa: UNDP Chandan, J. S. ( 1987). Management theory and practice.New York; Vikas Publishing House.

[19]. Chapman, A. (2005). Effective delegation skills, delegation techniques, process Retrieved on 10 October 2005 from http://www.businessballs.com/delegation.htm.

[20]. Choy.S.P.et.al.(1993).Schools and Staffing in the United States: A statistical profile 1990-91Avalible:ERIC Document Reproduction Services No 360378.

[21]. Collins D, Ross ATL (1989). Who wants participative management? The managerial perspective. Group and organization studies, pp 14:421-425.Cliffs: Prentice Hall.

[22]. Cole, G.A. (1996).Management Theory and Practice. London: DP Publication.

[23]. Cole, G. A.(2004).Management theory and practice. (6th ed.). London: TJ International Ltd.

[24]. Crum, K. S. \& Sherman, W. H. (2008). Facilitating High Achievement: High School Principals Reflections on their Successful Leadership Practices. Journal of Educational Administration .46(5), 562-580

[25]. Fiske, J. (1990). Introduction to communication studies(2nd ed.). London: Routledge.

[26]. Gambella Nation Nationalities Regional State,. (2000) Communication Bureau un published journal.

[27]. Gambella Nation Nationality Region State,.(1995). Revised Constitution (GNNRS) proclamation No 27/1997/3 Art47/30.Gambella Regional Government printing office.

[28]. Goldhaber, G. M. (1993). Organizational communication (6th ed.). Madison, Wi: Brown \& Benchmark.

[29]. Goldman, D. (2000).Leadership that gets results. Harvard Business Review.78- 90

[30]. Goldman, E. (2002). The significance of leadership style. Educational Leadership, 55(7), 20-22

[31]. Gronn, C. P. (1983). Talk as the work: The accomplishment of school administration. Administrative Science Quarterly 28(1), 121.

[32]. Gronn, P. (2000). Distributed properties: A new architecture for leadership.Educational Management \& Administration 28(3), 317338 .

[33]. Hackman, M.Z. \& Johnson, C.E. (2009). Leadership: A communication perspective, (5th ed.). Long Grove, IL: Waveland Press.

[34]. Hall, R. H. (2005). Organizations: structures, processes, and outcomes (9th ed.).Upper Saddle River, N.J.: Pearson Prentice Hall.

[35]. Handy, (1996). Job performance. all Street, Journal, May 12, 1984 pp B1, B

[36]. Hebert, E. (2011). The Relationship between Emotional Intelligence, Transformational Leadership, and Effectiveness in School Principals, Educational Policy Studies Dissertations, Georgia State University.

[37]. Inbar, D. (2009). Educational leadership in an era of contradictions, Educational Echo, 83 (4): 52-54.(Hebrew).

[38]. Stoner, (1982). The relationship between personality and leadership preference.

[39]. Zakaria, (2012). Leadership style of religious school headmasters and its relationship to academics achievement.

[40]. Ajanaku, (2012 and Darling-Hammond et al (2007). Educational leadership: reshaping high schools: creating excellence and equitable school-ASCD.

[41]. Kraus, (2008). The basis of distinction between qualitative and quantitative.

[42]. Fiedler, (1967). A theory of leadership effectiveness.

[43]. Gogura and Bassi, (2011). The relationship between level of education, teaching experience and job satisfaction among; National Commission for College of Education

[44]. Szilagyi and Willace, (1989). Organizational behaviour and performance.

[45]. Stogdill, (1978). Leadership "personal factors associated with leadersip".Gates et al, (2007). Young participation in higher education in the parliamentary Constituencies.

[46]. Adesina, (1989), a guild for students and teachers. 